\title{
MENJARING KONSUMEN DENGAN KONSEP BERORIENTASI STRATEGIS PEMASARAN
}

\author{
Akila *)
}

ABSTRAK

Konsep pemasaran adalah suatu falsafah manajemen dalam bidang pemasaran yang berorientasi kepada kebutuhan dan keinginan konsumen dengan didukung oleh kegiatan pemasaran terpadu yang diarahkan untuk memberikan kepuasan konsumen sebagai kunci keberhasilan organisasi dalam usahanya mencapau tujuan yang telah ditetapkan. strategi pemasaran adalah suatu langkah yang akan dijalankan dalam suatu kegiatan pemasaran guna mencapai tujuan dan bisa dapat menjadi pemimpin pasar. Pemasaran dipandang suatu hal yang penting kerena pemasaran berurusan dengan pemenuhan kebutuhan konsumen, salah satunya adalah memenuhi kebutuhan dengan cara yang menguntungkan. Oleh karena itu pemasaran umumnya dipandang sebagai tugas untuk menciptakan, memperkenalkan, dan menyerahkan barang dan jasa kepada konsumen dari perusahaan. Oleh karena itu konsep pemasaran mutlak harus dilakukan secara optimal, berhasil atau tidaknya suatu perusahaan tergantu dari konsep strategi pemasaran.

Kata Kunci : Konsep pemasaran, strategi pemasaran

\section{PENDAHULUAN}

Perkembangan globalisasi, kemajuan teknologi, dan deregulasi menunjukkan peluang yang tak habisnya. Perusahaan merupakan sesuatu yang tidak dapat di pisahkan dari perkembangan teknologi dan informasi. Semakin banyak kosumen, di setiap negara, semakin besar pula pasar dimana parah pembeli dan para perusahaan bebas untuk memutuskan apa yang harus dibuat dan dijual. Perusahaan besar dan perusahaan kecil bagi dunia bisnis, harus lebih inovatif dan kreatif dalam bersaing. Pemasaran berurusan dengan pemenuhan kebutuhan manusia, salah satunya adalah memenuhi kebutuhan dengan cara yang menguntungkan. Pemasaran umumnya dipandang sebagai tugas untuk menciptakan, memperkenalkan, dan menyerahkan barang dan jasa kepada konsumen dan perusahaan. Perusahaan menyadari bahwa strategi pemasaran memegang peranan penting dalam dunia usaha. Dengan adanya persainganpersaingan yang ketat dalam perdagangan, maka strategi pemasaran merupakan salah satu faktor penting untuk memasarkan produksinya.

$$
\text { Banyak }
$$

perusahaan maupun perorangan menganggap bahwa pemasaran kunci untuk mencapai tujuan organisasi. Pemasaran adalah proses sosial yang didalamnya individu dan kelompok mendapatkan apa yang dibutuhkan dan diinginkan dengan menciptakan menawarkan dan memerlukan produk yang bernilai. Sedangkan tujuan pemasaran adalah untuk mengatahui dan memahami pelanggan sedemikian rupa sehinga produk dan jasa itu cocok dengan pelanggan dan selanjutnya menjadi dirinnya sendiri.

Pemasaran memainkan
peranan yang penting dalam
proses perencanaan strategi
pemasaran. Pemasaran sebagai
pelaksanaan

*) Dosen Tetap Fakultas Ekonomi UPGRI Palembang 
penentapan harga, promisi, serta penyaluran gagasan barang dan jasa untuk menciptakan pertukaran yang memenuhi sasaran individu dan oragnisasi. Oleh karena itu perencanaan strategi pemasaran diperlukan untuk membentuk serta menyempurnakan usaha bisnis dan produk perusahaan sehingga target laba dan pertumbuhan.Dengan

memfokuskan pada perencanan strategi pemasaran membantu perusahaan mengelola usaha atau produk perkembangan perusahaan. Seorang pemasar mengatakan bahwa peran pemasaran adalah menghasilkan standar hidup yang lebih tinggi.

Konsumen membentuk harapan mereka berdasarkan pasar yang diterima dari penjual, teman, dan sumber-sumber informasi lain. Jika penjual melebih-lebihkan manfaat suatu produk, konsumen akan mengalami harapan tak tercapai, yang akan menyebabkan ketidakpuasan. Semakin besar kesengajaan antara harapan dan kinerja, semakin besar ketidakpuasan konsumen. Jika konsumen merasa tidak puas terhadap produk, maka akan mempengaruhi produk selanjutnya.

Strategi pemasaran adalah mengalokasikan dan mengkoordinasikan sumber daya dalam kegiatan pemasaran untuk mencapai tujuan perusahaan didalam produk pasar spesifik. Dapat disimpulkan bahwa strategi pemasaran adalah suatu langkah yang akan dijalankan dalam suatu kegiatan pemasaran guna mencapai tujuan dan bisa dapat menjadi pemimpin pasar. Tujuan dari setiap perusahaan bisa saja sama akan tetapi strategi yang dijalankan merupakan hal terpenting dalam pencapaian tujuan tersebut.

Konsep pemasaran adalah suatu falsafah manajemen dalam bidang pemasaran yang berorientasi kepada kebutuhan dan keinginan konsumen dengan didukung oleh kegiatan pemasaran terpadu yang diarahkan untuk memberikan kepuasan konsumen sebagai kunci keberhasilan organisasi dalam usahanya mencapau tujuan yang telah ditetapkan. Maka untuk menarik konsumen mencapai sasaran, pemasar menggunakan media elekteronik dan medei cetak sebagai alat komunikasi yang digunakan untuk menuju sasaran dari pemesan dan pembeli. Saluran komunikasi yang dimasud meliputi surat kabar, radio, televisi, telepon, papan iklan dan internet.

Dari urai diatas, maka saya diperlukan pengkajian tentang bagaiamana menjaring konsumen dengan perencanaan strategi berorientasi pemasaran sehingga memenuhi target laba dan pertumbuhan perusahaan.

\section{PEMBAHASAN}

Pertimbangan pertama yang harus dilakukan oleh perusahaan apabilah ingin merencanakan strategi berorientasi pemasaran.

\section{Memutuskan secara pasti apakah pemasaran bagi perusahaan.}

Perusahaan dapat mengkonsepkan pemasaran yang dapat digunakan sebagai tambahan bagi perusahaan didalam melaksanakan kegiatan pemasaran untuk menarik konsumen produk yang dipasarkan. Konsep ini merupakan suatu orientasi 
manajemen yang menekankan bahwa tugas utama perusahaan/ organisasi adalah menentukan kebutuhan, keinginan, dan kepentingan dari pasar yang dituju (sasaran) dan mengusahakan agar perusahaan/ organisasi tersebut dapat merasakan kepuasan yang diinginkan secara lebih efektif dan efisien dari para sainganya dalam meningkatkan dan melindungi kepentingan konsumen dan masyarakat.Strategi

pemasaran ini terdiri dari strategi harga, strategi saluran distribusi, strategi produk, dan strategi promosi.

Dengan memfokuskan pada target pasar, riset pasar, sasaran pemasaran, menawarkan mempromosikan produk, sebagai berikut.

\section{a. Target Pasar.}

Target pasar, kebanyak orang produk yang akan dipasarkan diharapkan akan banyak disukai oleh masyarakat dan bertahan lama dipasaran, sehingga keuntungan yang diperoleh dapat digunakan untuk menutupi resiko yang ada. Selain itu juga perusahaan tentunya mengharapkan peningkatan volume penjualan terus menerus tetapi perusahaan harus tahu bahwa setiap produk mengalami siklus hidup yang dapat berubah dari waktu ke waktu. Oleh karena itu harus ada upaya yang harus ditempuh organisasi atau perusahaan untuk mempengaruhi konsumen atau pelanggan didalam membeli suatu produk.

b. Riset pasar

$$
\begin{array}{lr}
\text { diolah } & \text { membantu } \\
\text { perusahaan } & \text { untuk } \\
\text { memutuskan dengan tepat } \\
\text { target pasar yang akan } \\
\text { dicapai. } & \text { Manajer } \\
\text { pemasaran } & \text { harus } \\
\text { mempelajari apa yang } \\
\text { tengah } & \text { dilakaukan }
\end{array}
$$
pesaing, cirri-ciri apa yang penting untuk sevuah produk agar berbeda dengan produk pesaing. Riset dapat membantu untuk memahami apa yang penting bagi pelanggan, apa yang ingin mereka ketahui dan dengan memeraka mencapainya.

c. Sasaran pemasaran .

Sasaran pemasaran produk yang telah dilempar kepasaran diharapkan akan banyak disukai oleh masyarakat dan bertahan lama dipasaran, sehingga keuntungan diperoleh dapat digunakan untuk menutupi resiko yang ada. Selain itu juga tentunya perusahaan mengharapkan peningkatan laba dan juga setiap produk mengalami siklus hidup yang dapat berubah dari waktu kewaktu.

\section{d. Menawarkan produk.}

Perusahaan harus mengatahui dengan pasti apa yang ditawarkan, perusahaan dapat melihat 
dengan 4 (empat) faktor, yaitu ,menawarkan sesuatu yang bernilai atau produk bagi konsumen baik itu berupa barang atau jasa, menetapkan harga pokok yang wajar, artinya penjual dan pembeli saling memperoleh manfaat dari produk tersebut, berusaha untuk mengkomunikasikan atau melakukan promosi atas manfaat produk yang dihasilkan kepada target pasar yang akan dilayani, merancang model distribusi yang mampu menjamin ketersediaan produkdiberbagai tempat dn situasi, menetapkan pemasaran apa yang dapat digunkan untuk mempromosikan suatu produk.

\section{e. Mempromosikan}

\section{Promosi}

adalah suatu bentuk komunikasi pemasaran yang di maksud komunikasi pemasaran adalah aktivitas pemasaran yang berusaha menyebarkan imformasi, mempengaruhi/membujuk, dan/atau mengingatkan pasar sasaran atas perusahaan dan produk atau barangnya agar bersedia menerima, membeli, dan loyal pada produk yang ditawarkan perusahaan yang
2. Menetapkan strategi apa yang dapat digunakan menjaring konsumen

$\begin{array}{lr}\text { Strategi } & \text { pemasaran, } \\ \text { mengalokasikan } & \text { dan } \\ \text { mengkoordinasikan } & \text { sumber } \\ \text { daya dalam } & \text { kegiatan }\end{array}$
pemasaran untuk mencapai tujuan perusahaan didalam produk pasar. Dalam penulisan ini, hanya lima konsep strategi pemsaran yang diambil, untuk digunakan kebutuhan dan keinginan konsumen dengan didukung oleh kegiatan pemasaran terpadu yang diarahkan untuk memberikan kepuasan konsumen. Konsep pemasaran yang dapat digunakan sebagai tambahan bagi perusahaan didalam melaksanakan kegiatan pemasaran, antara lain :
a. Konsep
produksi, manajemen
menganggap yang konsumen bahwa menyenangi produk-produk yang telah tersedia dan dapat dibeli. Akan tetapi konsumen menyenangi produk-produk yang telah tersedia tetapi belum dapat tertarik pada produk tersebut.
b. Konsep produk, manajemen yang menganggap konsumen akan lebih tertarik pada produk-produk yang ditawarkan dengan mutu yang terbaik pada tingkat harga tertentu. Namun konsumen belum tertarik pada produk-produk yang ditawarkan dengan mutu yang kurang baik pada tingkat harga ditentukan.
c. Konsep penjualan, manajemen yang 


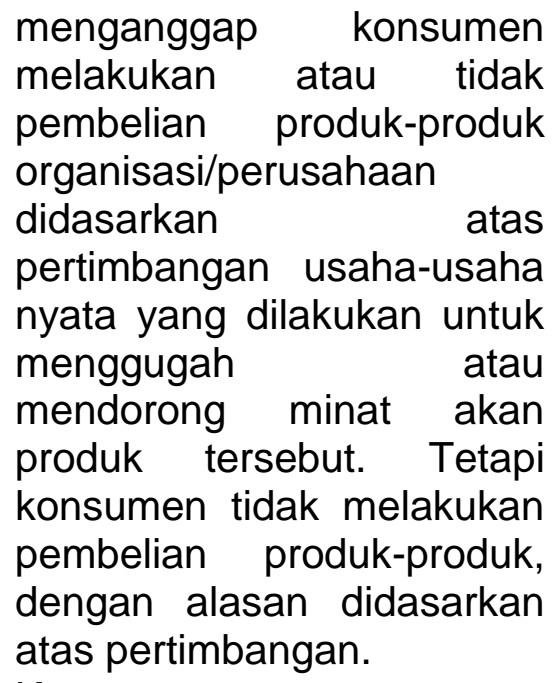

d. Konsep

pemasaran, manajemen yang menekankan bahwa kunci pencapaian tujuan organisasi menentukan kebutuhan dan keinginan pasar yang dituju (sasaran) dan kemampuan perusahaan/ organisasi tersebut memenuhinya dengan kepuasan yang diinginkan secara lebih efektif dan efisien dari para pesaing. Akan tetapi keinginan pasar yang ditujuh sasarannya dan kemampuan perusahaan tersebut belum memenuhi kepuasan yang diinginkan.

e. Konsep pemasaran ke masyarakat, manajemen yang menekankan bahwa tugas utama perusahaan/ organisasi adalah menentukan kebutuhan, keinginan, dan kepentingan dari pasar yang dituju (sasaran) dan mengusahakan agar perusahaan/ organisasi tersebut dapat memnuhi kepuasan yang diinginkan secara lebih dari para sainganya dalam meningkatkan dan melindungi kepentingan konsumen dan masyarakat. Namun kebutuhan, keinginan, kepentingan kosumen mengusahakan agar perusahaan belum dapat memenuhi kepuasan yang diinginkan secara lebih efektif dan efisien dalam meningkatkan dan melindungi kepentingan konsumen dan masyarakat.

\section{KESIMPULAN}

Pemasaran dipandang suatu hal yang penting kerena pemasaran berurusan dengan pemenuhan kebutuhan konsumen, salah satunya adalah memenuhi kebutuhan dengan cara yang menguntungkan. Oleh karena itu pemasaran umumnya dipandang sebagai tugas untuk menciptakan, memperkenalkan, dan menyerahkan barang dan jasa kepada konsumen dari perusahaan. Dengan demikian perusahaan menyadari bahwa adanya persaingan-persaingan yang ketat dalam perdagangan, maka konsep strategi pemasaran merupakan salah satu faktor penting untuk memasarkan produksinya.

Konsep pemasaran masih dianggap sebagai suatu hal yang belum begitu menarik bagi konsumen utuk membeli produk yang dipasarkan. Karena tidak secara otomatis konsumen membuat keputusan untuk membeli produk tersebut, ini sering terjadi konsumen masih belum merasa puas produk yang ditawarkan sehingga sasaran untuk kepuasan yang diinginkan belum tercapai.

Oleh karena itu konsep pemasaran mutlak harus 
dilakukan secara optimal, berhasil atau tidaknya suatu perusahaan tergantu dari konsep strategi pemasaran.

\section{DAFTAR PUSTAKA}

Alma, Buchari, 2009, Manajemen Pemasaran dan Pemasaran Jasa, Alfabeta, Bandung.

Kotler \& Gary Amstrong, 2012, PrinsipPrinsip Pemasaran, Edisi Ketiga Belas, Erlangga, Jakarta.

Kotler \& Kaller, 2009, Manajemen Pemasaran, Edisi Ketiga Belas, Indeks, Jakarta.

Sunarto, 2004, Manajemen

Pemasaran, Univ.Sarjanawijaya Tamansiswa PRESS, Yokyakarta

Tjiptono, Fandy, 2008, Strategi Pemasaran, Edisi Ketiga, Andi Offset, Yogyakarta.

Widiana, Erma, Muslichah \& Sinaga, Bonar, 2010, Dasar-Dasar Pemasaran, Putra Dawati, Bandung. 